MONIKA PIOTROWSKA-MARCHEWA

https://orcid.org/0000-0003-3136-9348

Uniwersytet Wrocławski

\title{
NAUCZYCIELKI LUDOWE. UWARUNKOWANIA PRACY KOBIET W PUBLICZNEJ OŚWIACIE POWSZECHNEJ POLSKI MIĘDZYWOJENNEJ
}

Zarys treści: Artykuł podejmuje zagadnienie uwarunkowań pracy kobiet w publicznej oświacie powszechnej w II Rzeczypospolitej, na podstawie analizy wybranych materiałów prasowych, archiwalnych i statystycznych. Autorka rozważa, czy polityka państwa polskiego w okresie międzywojennym sprzyjała wchodzeniu kobiet w struktury oświaty powszechnej i utrwalaniu ich pozycji zawodowej. Koncentruje się zarówno na emancypacyjnych walorach zawodu nauczycielki ludowej i możliwościach realizowania się w szkolnictwie powszechnym przez kobiety, jak też na przejawach strukturalnych nierówności w dostępie do tego zajęcia.

The content outline: The article discusses the issue of working conditions of female teachers in public mainstream education in the Second Polish Republic. The analysis is based on selected press publications, archival materials, and statistical data. The author studies the question of whether the state policy of the Second Polish Republic promoted the involvement of women in the mainstream education structures and strengthened their professional standing. The work focuses both on the advantages of working as a folk teacher and women's opportunity for self-fulfillment in mainstream education and on the examples of structural inequality in the access to the aforementioned career.

Słowa kluczowe: nauczycielki, nauczycielki ludowe, szkolnictwo powszechne, oświata publiczna, Polska 1918-1939, II Rzeczpospolita, praca kobiet, kobiety

Keywords: female teachers, folk teachers, mainstream education, public education, Poland 1918-1939, Second Polish Republic, women's work, women 
Możliwość podjęcia aktywności zawodowej w systemie szkolnictwa Polski międzywojennej stworzył kobietom - na nieporównywalną wcześniej skalę - będący wówczas nowością nieograniczony dostęp do edukacji wszystkich szczebli oraz dynamiczny rozwój oświaty, wraz z wprowadzeniem w 1919 r. powszechnego obowiązku szkolnego na szczeblu elementarnym. Jednocześnie w okresie międzywojennym zauważalnie wzrosła rola edukacji jako takiej i znaczenie wykształcenia, co wraz ze stabilnością posad w szkolnictwie państwowym dodawało atrakcyjności pracy nauczycielskiej ${ }^{1}$. Celem niniejszego artykułu jest charakterystyka uwarunkowań pracy kobiet w publicznej oświacie powszechnej w II Rzeczypospolitej. Jak wskazuje analiza wybranych materiałów prasowych, archiwalnych i statystycznych, z której wnioski przybliżam w dalszej części artykułu, z jednej strony nie sposób przecenić emancypującego charakteru tego zajęcia, zarówno w wymiarze społecznym, jak i feministycznym, z drugiej natomiast wskazać można przykłady strukturalnych nierówności w dostępie do zawodu i w możliwości realizowania się w nim kobiet. Nadrzędnym przedmiotem rozważań pozostaje kwestia, czy polityka państwa polskiego w okresie międzywojennym sprzyjała wchodzeniu kobiet w struktury oświaty powszechnej i utrwalaniu ich pozycji zawodowej.

W warunkach świeżo odzyskanej niepodległości nauczycielki stanowiły ponad połowę pracowników tego sektora edukacji, przy czym w początkach omawianego okresu było ich więcej niż w kolejnej dekadzie. W pierwszej połowie lat dwudziestych XX w. kobiety przeważały wśród nauczycieli szkół powszechnych zarówno w byłej Galicji, jak i w pozostałych częściach kraju (stanowiąc od 56 do $67 \%$ ogółu nauczycieli). Wyjątek stanowiły jedynie Ślassk Cieszyński (21,2\% ogółu nauczycieli) i województwo pomorskie $(34,6 \%)$. W województwach wołyńskim i poznańskim stanowiły one odpowiednio 49 i 49,3\% ogółu zatrudnionych². Według

${ }^{1}$ Zjawisko to odnotowywano w prasie specjalistycznej. „Od chwili poprawy bytu nauczycielskiego - różne jednostki, które dawniej ze wstrętem odwracały się od tego zawodu, przypomniały sobie, iż kiedyś zdały maturę, a uczuwszy nagle powołanie, tłumnie zgłaszają się do służby, do której najmniejszego pociagu nie miały, zaś posiadając wyrobione stosunki miejscowe, bez trudu bywaja przyjmowane ze szkodą dla szkoły, społeczeństwa i nauczycielstwa. Podobny proceder należy bezwarunkowo tępić, zaś obowiązkiem nauczycielstwa jest pilnować i przeciwdziałać, by podobnych jednostek do zawodu nie dopuszczać”, za: „Głos Nauczycielski” 1921, nr 6-7, s. 67. Przywołane argumenty świadczą m.in. o trosce o budowanie prestiżu zawodu nauczyciela szkoły ludowej.

${ }^{2}$ E. Juśko, Wpływ szkolnictwa ludowego autonomicznej Galicji na ksztatt polskiej szkoty powszechnej w latach 1918-1922, Lublin 2006, s. 211-212; S. Walasek, Nauczyciele szkót średnich w Polsce w roku 1922/23 jako grupa społeczna, w: Oświata, 
danych z połowy lat trzydziestych mapa zatrudnienia przybrała bardziej równościowy charakter: w publicznych i państwowych szkołach powszechnych zatrudnionych było 39979 kobiet (tj. „tylko” 54,9\%) ${ }^{3}$, co wiązało się ze znaczną liczbą męskich kandydatów do zawodu rolę odgrywała wówczas trudna sytuacja na rynku pracy i gwarantowane przez system szkolnictwa, wprawdzie niewielkie, ale stałe dochody ${ }^{5}$. Wśród mężczyzn pracujących w publicznych i państwowych szkołach powszechnych (32 742 osób) w roku szkolnym 1935/1936 w miastach pracowało $24,8 \%$, a na wsiach $-75,1 \%$. W odniesieniu do nauczycielek w miastach było ich $30,6 \%$, a na wsiach - 69,3\% ogółu zatrudnionych w szkolnictwie kobiet ${ }^{6}$.

Nauczyciele szkół powszechnych w okresie międzywojennym w znacznym odsetku rekrutowali się z warstw ludowych i drobnomieszczaństwa. Dla młodzieży wiejskiej główna droga awansu społecznego wiodła właśnie poprzez seminaria nauczycielskie ${ }^{7}$; tą jednakże różnica, że wciąż była ona relatywnie bardziej dostępna dla młodzieży męskiej. Wskazuje na to fakt, że więcej nauczycieli niż nauczycielek miało pochodzenie chłopskie i robotnicze: w pierwszych latach po wojnie dotyczyło ono $52 \%$ mężczyzn i $22,4 \%$ kobiet. W seminariach żeńskich natomiast nadal - podobnie jak przed I wojną światową - przeważały córki niższych urzędników i drobnomieszczaństwa, które w pracy tej (niezależnie od priorytetu zamążpójścia) widziało odpowiedni dla nich model

szkolnictwo i wychowanie w latach II Rzeczypospolitej. Materiaty Ogólnopolskiej Sesji Naukowej, Lublin 7-8 listopada 1988 roku, red. K. Poznański, Lublin 1991, s. 136.

${ }^{3}$ Nauczyciele $w$ liczbach. Liczebność, cechy osobowe, zatrudnienie, uposażenie 1935/36, red. M. Falski, Warszawa 1938, s. 8.

4 J. Żarnowski, Kobiety $w$ strukturze społeczno-zawodowej Polski międzywojennej, w: Równe prawa i nierówne szanse. Kobiety $w$ Polsce międzywojennej. Zbiór studiów, red. A. Żarnowska, A. Szwarc, Warszawa 2000, s. 103.

${ }^{5}$ K. Sanojca, Szkoła jako instytucja pracy. Pozycja prawna i problemy zawodowe nauczycieli szkót państwowych w okresie Drugiej Rzeczypospolitej, w: Praca i społeczeństwo Drugiej Rzeczypospolitej, red. W. Mędrzecki, C. Leszczyńska, Warszawa 2014 (Metamorfozy Społeczne, 9), s. 282.

${ }_{6}$ Tamże.

${ }^{7}$ R. Cierzniewska, Kształtowanie umiejętności zawodowych w seminariach nauczycielskich Drugiej Rzeczypospolitej, Torun 2008, s. 107. Było to skutkiem słabo rozwiniętego szkolnictwa zawodowego oraz niedostępności elitarnych gimnazjów i liceów. Warto podkreślić rosnąca obecność kobiet w zawodzie nauczycielskim w porównaniu do epoki przedwojennej. Do szkolnictwa elementarnego na ziemiach polskich nauczycielki wkroczyły w większej liczbie dopiero w drugiej połowie XIX w. Przed I wojna światową zarówno w autonomicznej Galicji, jak i w Królestwie Polskim nauczycielki pracowały przeważnie w szkołach miejskich, natomiast szkoły wiejskie zatrudniały głównie mężczyzn; zob. A. Smołalski, Struktura zawodowa nauczycielstwa w Polsce do 1939 roku, Opole 1996, s. 51. 
kariery zawodowej, gwarantującej wyższy status społeczny niż zawód pielęgniarki, telefonistki czy asystentki biurowej, i niekiedy nawet za cenę wyrzeczeń gotowe było łożyć środki na jego realizację . $^{2}$

W Polsce międzywojennej nauczycielstwo było pierwszym zawodem użyteczności publicznej, w którym wyrównaniu uległy zarobki, wcześniej różnicowane w zależności od płci. W praktyce jednak, jak wynika z danych statystycznych, relatywnie mniej kobiet niż mężczyzn było zakwalifikowanych do lepiej płatnych grup uposażeniowych. Przy czym w kwestii tej istniało znaczne zróżnicowanie, w zależności od regionu kraju. Szczególnie widoczne było to na Górnym Ślassku9 .

Tabela 1. Nauczycielki i nauczyciele szkolnictwa powszechnego w Polsce (bez województwa ślaskiego) według grup uposażeniowych (1935/1936)

\begin{tabular}{|l|c|c|c|r|r|r|}
\hline \multirow{2}{*}{$\begin{array}{c}\text { Grupa } \\
\text { uposa- } \\
\text { żenia }\end{array}$} & \multicolumn{2}{|c|}{ ogółem } & \multicolumn{2}{c|}{ w miastach } & \multicolumn{2}{c|}{ na wsi } \\
\cline { 2 - 7 } & M & K & M & \multicolumn{1}{c|}{ K } & M & \multicolumn{1}{c|}{ K } \\
\cline { 2 - 7 } VI & 109 & 51 & 101 & 50 & 8 & 1 \\
\hline VII & 1764 & 1084 & 833 & 691 & 931 & 393 \\
\hline VIII & 4031 & 4409 & 1413 & 2456 & 2618 & 1953 \\
\hline IX & 10250 & 13776 & 2437 & 4969 & 7813 & 8807 \\
\hline X & 9857 & 15041 & 1528 & 2372 & 8329 & 12669 \\
\hline XI & 1691 & 1145 & 113 & 111 & 1578 & 1038 \\
\hline Ogółem & 27762 & 35563 & 6449 & 10678 & 21313 & 24885 \\
\hline
\end{tabular}

Źródło: oprac. własne na podstawie: Nauczyciele w liczbach. Liczebność, cechy osobowe, zatrudnienie, uposażenie 1935/36, red. M. Falski, Warszawa 1938, s. 117.

W skali całego kraju (zob. tabela 1) również większość nauczycielek $(84,2 \%)$ zostało zakwalifikowanych do trzech najniższych grup uposażeniowych (w przypadku nauczycieli było ich „tylko” 78,5\%). Jednak

8 J. Żarnowski, dz. cyt., s. 103; T. Szczechura, Zwiazek Nauczycielstwa Polskiego: zarys dziejów 1919-1939, Warszawa 1957, s. 41. Podejmowanie pracy w zawodzie nauczycielskim świadczyło o awansie społecznym kobiet - stawały się osobami publicznymi, a otrzymane wynagrodzenie było ekwiwalentem pieniężnym za wykonywaną pracę; A. Glimos-Nadgórska, Polskie szkolnictwo powszechne województwa ślaskiego 1922-1939, Katowice 2000, s. 180.

${ }^{9} \mathrm{~W}$ szkolnictwie powszechnym województwa śląskiego aż 84\% nauczycielek (1571 z 1858 kobiet) zostało zakwalifikowanych do trzech najniższych grup uposażeniowych, w wyższych grupach uposażeniowych było ponad dwa razy więcej mężczyzn niż kobiet (800 do 287); A. Glimos-Nadgórska, Nauczyciele i nauczycielki: zróżnicowanie szans $w$ zawodzie $w$ województwie ślaskim $w$ okresie międzywojennym, w: Kobieta $i$ praca. Wiek XIX $i$ XX. Zbiór studiów, t. 6, red. A. Żarnowska, A. Szwarc, Warszawa 2000, s. $169 \mathrm{nn}$. 
w trzech wyższych grupach uposażeniowych liczba mężczyzn i kobiet była zbliżona (5904 do 5544) ${ }^{10}$. Jeszcze inny obraz wyłania się przy rozpatrywaniu danych w podziale miasto - wieś. W miastach $69,7 \%$ kobiet było zakwalifikowanych do trzech najgorzej płatnych grup (XI-IX), mężczyzn natomiast $63,2 \%$; jednak w trzech wyższych grupach uposażeniowych nauczycielek było więcej niż nauczycieli (3197 kobiet i 2347 mężczyzn). Zważywszy na opisane wcześniej różnice w pochodzeniu społecznym nauczycielstwa szkół powszechnych, wśród którego więcej kobiet niż mężczyzn wywodziło się z rodzin inteligenckich i drobnomieszczańskich, dysproporcja ta zdaje się mieć właśnie klasowe uzasadnienie. Wskazać należy jednak i inny czynnik, natury obyczajowej. Otóż na wsi proporcje związane z płacami przedstawiały się bardziej niekorzystnie dla kobiet: $90,4 \%$ nauczycielek i $83,1 \%$ nauczycieli znalazło się we wspomnianych trzech najniższych grupach uposażeń, a w trzech najwyższych: 2347 kobiet i aż 3557 mężczyzn. Pośrednio oznacza to, że zbliżone proporcje zatrudnienia pod względem płci oraz wykształcenia wśród osób zatrudnionych na wsi (21 313 nauczycieli i 24885 nauczycielek) nie przekładały się bynajmniej na gwarancję równorzędnych zarobków, których wysokość zależała jedynie od liczby przepracowanych lat ${ }^{11}$. Jak się wydaje, utrzymujaccy się na wsi tradycyjny model rodziny, właściwy także obyczajowości górnośląskiej, sprawiał, że kobiety często przerywały pracę zawodowa, wychodząc za mąż lub rodząc dzieci, co miało istotny wpływ na ich zarobki. Nakładało się na to po części również oddziaływanie ustawodawstwa „celibatowego”, z różnym natężeniem wymuszajacego opuszczanie szeregów nauczycielstwa przez mężatki (co wpływało na ogólne proporcje płci wśród zatrudnionych), do którego powrócę w dalszej części artykułu.

Mimo rewolucyjnych zmian w zatrudnieniu, jakie przyniosła I wojna światowa oraz względnie egalitarnego charakteru tej grupy zawodowej, kobiety rzadziej zajmowały stanowiska kierownicze. W połowie lat trzydziestych XX w. w szkołach publicznych i państwowych 1 kobieta przypadała na 5 mężczyzn (na 4834 kierowników mężczyzn przypadało 977 kobiet), w przypadku osób „pełniących obowiązki kierowników” proporcje te kształtowały się 1:4 (tj. na 6138 mężczyzn było 1621 kobiet) ${ }^{12}$. Poza tymi statystycznymi ustaleniami zespołu pod kierunkiem Mariana Falskiego z połowy lat trzydziestych nie dysponujemy jednak wystarczającymi danymi, które pozwoliłyby ocenić, czy proporcje te oznaczały

\footnotetext{
${ }^{10}$ Wyliczenia własne na podstawie: Nauczyciele $w$ liczbach..., s. 117.

11 Tamże.

${ }^{12}$ Wyliczenia własne na podstawie: Nauczyciele $w$ liczbach..., s. 26.
} 
postęp względem poprzedniej dekady, czy raczej odzwierciedlały wciąż niezachwiany patriarchalny porządek, faworyzujący mężczyzn. W opinii Haliny Siemieńskiej, wypowiadającej się w 1930 r. na łamach „Kobiety Współczesnej”, fakt utrzymywania się tej dysproporcji i „rezerwowania sobie stanowisk kierowniczych przez mężczyzn" (podobnie jak stanowisk inspektorów, wizytatorów, etc.), mimo rosnącej liczby kobiet w szkolnictwie i mimo że od tego zawodu „mężczyźni zaczynają stronić”, był zjawiskiem negatywnym i przedmiotem troski kobiet zaangażowanych w działalność feministyczna ${ }^{13}$.

Warto zadać pytanie, czy powyższe dane (odczytywane w środowiskach feministycznych jako „rezerwowanie sobie stanowisk kierowniczych przez mężczyzn”) postrzegać można jako przejaw swoistego „odzyskiwania” posad przez mężczyzn, skoro dekadę wcześniej - wskutek uczestnictwa w walkach zbrojnych o ustalenie granic II Rzeczypospolitej oraz w wojnie polsko-bolszewickiej - z opóźnieniem względem kobiet podejmowali oni prace zawodowa w wolnej Polsce? W zarysowanym powyżej kontekście jako interesujący przykład (który nie może być podstawą uogólniającego sądu, a jedynie hipotezy, gdyż jest pojedynczym sygnałem, zachowanym $\mathrm{w}$ archiwum) jawi się list z 18 VI $1920 \mathrm{r}$. skierowany w trakcie trwania konfliktu o przynależność państwowa ziemi wileńskiej przez wileńskiego inspektora szkolnego, pracownika Inspektoratu Szkolnego m. Wilna przy Zarządzie Cywilnym Ziem Wschodnich ${ }^{14}$ do miejscowego proboszcza. Stanowi dość kategoryczna, odmowną odpowiedź na jego pismo polecające kandydaturę nauczycielki na posadę kierowniczki szkoły ${ }^{15}$ : „Do Księdza Proboszcza T. Zawadzkiego, na Antokolu. Odpowiadajac na list Szanownego Ks. Proboszcza z dn. 11 b.m., komunikuję, że zgodzić się na kandydaturę p. M. Bartoszewiczówny nie mogę dlatego, że: 1) w szkołach pożądane jest oddawanie ich kierownictwa w ręce mężczyzn, tembardziej w Wilnie, gdzie tych mężczyzn wśród nauczycielstwa jest nieproporcjonalnie zamało [sic!],

${ }^{13}$ H. Siemieńska, Najpilniejsze zagadnienia feminizmu w Polsce, „Kobieta Współczesna" 1930, nr 19, s. 2.

${ }_{14}$ Nieczytelne nazwisko w dokumencie, pisanym ręcznie.

15 „Mam honor przedstawić do zatrudnienia na kierowniczkę szkoły im. Piotra Skargi Antokolskiego Koła P[olskiej] Macierzy Szkolnej ([...] szkoła powszechna nr 29) p. Marię Bartoszewiczównę nauczycielkę wykwalifikowaną, nauczającą dotychczas w szkołach Towarzystwa "Caritas" na Zarzeczu. Skład personelu nauczycielskiego wyklaruje się dopiero po zatrudnieniu przez P. Inspektora nowej kierowniczki. [...] $\mathrm{Na}$ rok szkolny następny przewidujemy otworzenie piątego oddziału. Prezes Koła T. Zawadzki. 11 czerwca 1920"; Lietuvos Centrinis Valstybės Archyvas, f. 172, Kuratorium Okręgu Szkolnego Wileńskiego, Ministerstwo Wyznań Religijnych i Oświecenia Publicznego, ap. 1, b. 108, k. 3. 
2) posadę kierownika szkoły Nr. 29 już na początku maja r.b. przyrzekłem nauczycielowi rutynowanemu, którego z b. Królestwa w maju sprowadziłem. W odpowiedzi zaś na list $\mathrm{z}$ dn. 18 b.m. ${ }^{16}$ uprzejmie komunikuję, że szkoła Nr 29 nie korzysta z subsydjum rządowego, lecz całkowity koszt prowadzenia jej, a więc: opał, lokal, papier, pensje nauczycielstwa i.t.p. - ponosi skarb Państwa, zatem słuszna, że to Państwo, w osobie Inspektoratu, ma pierwszy głos $\mathrm{w}$ dobieraniu personelu nauczycielskiego. Inspektorat szkolny jest zasadniczo [instytucja - M.P.-M.] pedagogiczna, nic dziwnego zatem, że życiem szkoły chce kierować, bo za nie jest odpowiedzialny. Ingierencja [sic!] społeczeństwa jest pożądana, lecz ona nie może posuwać się do tego, [aby] krępowała mocno poszczególne organy władzy Państwowej w wykonywaniu zasadniczych i głównych czynności (jak w tym wypadku obsadzania posad), do których sa powołane. I tak, podczas feryj letnich Inspektorat sam ustali sieć szkolna i poobsadza nauczycielstwo w szkołach według swego uznania, w tym zaś wypadku, kiedy będzie potrzebował pomocy społeczeństwa, zawsze o tę pomoc się zgłosi i za nią [będzie - M.P.-M.] wdzięczny. Proszę zatem nie mieć mi za złe, że na kandydaturę p. M. Bartoszewiczówny, jako kierownika szkoły, bom się już słowem z inną osobą związał, ale za to chętnie będę ją widział na stanowisku nauczycielki w szkole nr. 29"17. Dodać warto, że w roku szkolnym 1918/1919 do polskich szkół w Wilnie uczęszczało 5892 uczniów, a organizowano je pomimo olbrzymich braków kadrowych i materialnych ${ }^{18}$. Reakcja inspektora szkolnego wobec kandydatury Marii Bartoszewiczówny wskazuje przede wszystkim na wyraźne napięcie na linii: reprezentant polskiej administracji szkolnej a przedstawiciel lokalnej władzy kościelnej. Wilno było ówcześnie scena ostrych konfliktów między środowiskami bliskimi Naczelnikowi Państwa Józefowi Piłsudskiemu a przedstawicielami polskich środowisk nacjonalistycznych ${ }^{19}$, być może u podłoża leżały też występujące wśród

${ }^{16}$ W kolejnym liście, nie doczekawszy się najwyraźniej odpowiedzi na poprzedni, ks. Zawadzki pisał: „Nie dziwię się, że w rodzącej się naszej Ojczyźnie natrafiamy na rozmaite niespodzianki lub tarcia. Otóż taką niespodzianka, podobno, było dla Szanownego Pana moje zwrócenie się z prośbą o zatwierdzenie kierowniczki szkoły [...]. Uczyniłem to na mocy wyjaśnienia Szefa Okręgu Wileńskiego p. Zarzyckiego, które mi zakomunikował p. W. Węcławski Prezes Macierzy. "Szkoły społeczne (w których uczniowie nie opłacają za naukę) korzystają z subsydium żądowego [sic!] wystarczającego do owej egzystencji maja prawo dobierania sobie personelu nauczycielskiego«. Z wysokiem poważaniem. Ks. Tadeusz Zawadzki. 18 czerwca 1920”; tamże, k. 4.

17 Tamże, k. 6.

18 J. Januszewska-Jurkiewicz, Stosunki narodowościowe na Wileńszczyźnie $w$ latach 1920-1939, Katowice 2010, s. 131.

19 Tamże, s. 127. 
nauczycielstwa ludowego nastroje antyklerykalne, wreszcie dążenie do potwierdzania swojego statusu wobec przedstawicieli lokalnych elit. Czy niezależnie od faktu, że wspomniana nauczycielka nie otrzymała posady obiecanej komuś innemu, powodem odrzucenia jej kandydatury mogła być także zbyt mała liczba mężczyzn w lokalnych strukturach szkolnictwa, nie sposób jednak rozstrzygnacic ${ }^{20}$.

Inaczej sprawy się miały, gdy zachodziła konieczność redukcji etatów w szkolnictwie, motywowanych aktualna sytuacją ekonomiczna państwa. Na tym polu rzeczywiście ujawniało się dążenie do „odzyskiwania” posad dla mężczyzn, zarówno w naznaczonym gigantyczną inflacja okresie tużpowojennym, jak i w czasie Wielkiego Kryzysu, w powiązaniu z obowiązującym prawem. Uwagę w nim kierowano na nauczycielki i ich stan cywilny, a nie liczebność mężczyzn. Ustanowione w okresie międzywojennym przepisy prawne umożliwiały bowiem zwalnianie z posad zamężnych urzędniczek i nauczycielek: w 1924 r. weszło w życie zarządzenie, które pozwalało zwalniać z pracy zamężne urzędniczki. Objęło ono również nauczycielki, a jego oddziaływanie nasiliło się zwłaszcza w okresie Wielkiego Kryzysu, w ramach ogólnej tendencji do przeprowadzania redukcji wśród kobiet $\mathrm{w}$ przedsiębiorstwach i instytucjach państwowych, czyli tam, gdzie najłatwiej było regulować zatrudnienie ${ }^{21}$. W województwie ślaskim podobne prawo zyskało rangę ustawy autonomicznego Sejmu Śląskiego „w sprawie rozwiązania stosunku służby nauczycielskiej wskutek zawarcia przez nauczycielkę związku małżeńskiego". Od marca 1926 r. na jej mocy nie tylko zaczęto zwalniać mężatki, ale też wymagać od kobiet „stanu wolnego”, jeśli chciały uprawiać zawód nauczycielki ${ }^{22}$. Towarzyszyło temu anachroniczne już przekonanie twórców prawa, że kobiety zamężne nie muszą starać się o własne

${ }^{20}$ Dane statystyczne dotyczące personalnego składu szkół powszechnych $\mathrm{m}$. Wilna z kwietnia 1924 r. potwierdzaja konstatację autora listu, chociaż nie usprawiedliwiają intencji. Informują one, że liczba nauczycieli w tamtejszych polskich szkołach powszechnych wynosiła ogółem 316 osób, w tym 44 mężczyzn (13,9\%). Wśród zatrudnionych kobiet było 211 nauczycielek niezamężnych oraz 61 mężatek; Lietuvos Centrinis Valstybės Archyvas, f. 172, Kuratorium Okręgu Szkolnego Wileńskiego, Ministerstwo Wyznań Religijnych i Oświecenia Publicznego, ap. 1, b. 1000, k. 120-126.

${ }^{21}$ J. Żarnowski, dz. cyt., s. 102.

22 A. Glimos-Nadgórska, Nauczyciele i nauczycielki..., s. 169 nn. Według ślaskiej ustawy z 1926 r. zwolnieniu z pracy podlegały nauczycielki, które były mężatkami, z wyjątkiem nauczycielek robót kobiecych i nauczycielek kontraktowych. Wśród mężatek pracować mogły jedynie te, które miały już pełne kwalifikacje zawodowe i staż pracy przekraczający rok. Ustawę potwierdził później dekret prezydenta z $1933 \mathrm{r}$. W ten sposób wyrażała się motywowana politycznie aprobata władz sanacyjnych względem autonomii Śląska oraz brak większego zainteresowania tychże władz kwestią zwalnianych nauczycielek. 
utrzymanie. W ich efekcie posady częściej traciły kobiety, bez oglądania się na ich kompetencje, a nawet sytuację życiową (np. bezrobocie męża).

Napięcia natury społecznej sprawiały wszakże, że postulat redukcji etatów kobiecych cieszył się poparciem także wśród niemałej liczby nauczycieli i nauczycielek. Wskazuje na to „socjologiczna” analiza przeprowadzona w 1925 r. przez nauczyciela Filipa Głąka na łamach organu zwiazkowego Zwiazkku Nauczycielstwa Polskiego - „Głosu Nauczycielskiego”. Autor artykułu podkreślał, że odejść ze szkoły w ramach redukcji etatów powinny te „uprzywilejowane panie, [które] tylko szkołom w miastach robia zaszczyt”. Pytał w nim retorycznie: „Dlaczego nie pójdą na wieś na posady, aby zrobić miejsce koleżankom, które na wsi długie lata służą i zasługują na awans w mieście?". Autor listu podawał następujące kandydatury do redukcji: żona urzędnika państwowego, leśniczego, nauczyciela gimnazjalnego i sędziego ${ }^{23}$. W jednym z kolejnych numerów pisma redakcja informowała o polemicznym głosie nauczycielki Zofii Janiszewskiej, która starała się brać mężatki w obronę, sama jednak zajęła stanowisko przychylne redukcjom wśród kobiet ${ }^{24}$.

Postulat zwalniania z pracy kobiet zamężnych nabrał mocy szczególnie podczas kryzysu gospodarczego przełomu lat dwudziestych i trzydziestych. Przykładowo „Prawda Pabianicka” pisała w 1934 r. o swojej walce „przy akompaniamencie wrzasku rodzimych emancypantek - o zwolnienie mężatek, których mężowie pracuja”, obwieszczając, że „miejsca mężatek muszą zając bezrobotni pracownicy umysłowi - ojcowie rodzin, których warunki materialne przekraczaja już dawno minimum egzystencji. A tego domaga się zwykła sprawiedliwość społeczna”25. Charakterystyczny jest jednostronny ton tej enuncjacji, który utratę pracy przez zamężne kobiety traktuje jako sukces, natomiast jeśli bezrobocie dotyczy mężczyzn (,pracowników umysłowych, ojców rodzin”) jako fakt przeczacy „zwykłej sprawiedliwości społecznej”.

Z kolei wśród tej części nauczycielstwa, które nie akceptowało redukcji wśród mężatek, strach przez zwolnieniem osiagał poziom zbiorowej

${ }^{23}$ F. Głąbek, Kto ocalał przed redukcja, „Głos Nauczycielski” 1925, nr 5, s. 73-74.

24 „Poglądy Szan. Koleżanki na redukcję są najzupełniej słuszne, generalizować przykładów kol. Filipa Głąbka z jego artykułu [...] nie można, [...], ale też kol. Głąbek [...] dał tylko przykłady ujemne. Biorąc pod uwagę przykłady dodatnie - godzimy się całkowicie z Koleżanka, że cały szereg żon wyższych urzędników spełnia wzorowo i z powołaniem obowiązki wychowawcze w szkole. Tych jednak jest tak niewiele, niewiele. I słusznie Koleżanka konkluduje: »Kogo redukować? Nikogo! Ale w wypadkach koniecznych - stanowczo ubogich duchem". My od siebie dodamy: leniących się w pracy i wyzyskujących stanowiska swych mężów”; Odpowiedzi Redakcji, „Głos Nauczycielski” 1925, nr 8, s. 157.

25 „Prawda Pabianicka”, 14 X 1934. 
paniki. Dowodem jest choćby komunikat „Głosu Nauczycielskiego” z 1933 r., w którym redakcja pisma musiała uspokajać czytelników, że wyniki świeżo rozpisanej ankiety o stanie rodzinnym nauczycieli szkół powszechnych nie będą podstawą do zwalniania nauczycielek ${ }^{26}$. Trudno się dziwić tym reakcjom, skoro w tym samym roku Kuratorium Okręgu Szkolnego Poznańskiego zajęło się sporządzaniem szczegółowego spisu mężatek zatrudnionych $\mathrm{w}$ tamtejszym szkolnictwie powszechnym ${ }^{27}$. Prasa kobieca próbowała tonować te nastroje. Helena Radlińska, ówczesna dziekan Wydziału Pedagogicznego Wolnej Wszechnicy w Warszawie i kierowniczka Studium Pracy Społecznej, w wywiadzie streszczonym na łamach „Kobiety Współczesnej” w 1931 r. wyjaśniała: „Jeżeli chodzi o perspektywy w zawodzie nauczycielskim, to rzeczywiście nie sa one zbyt dobre. Zwłaszcza w szkolnictwie średniem poprawa zapewne nie nastapi prędko. W szkolnictwie powszechnem natomiast napływ dzieci wzrasta, więc redukcje są przejśsiowe i mina, gdy minie panika oszczędnościowa"28.

Ogólna liczba mężatek zatrudnionych w państwowych i publicznych szkołach powszechnych w połowie lat trzydziestych zdaje się potwierdzać konstatację Radlińskiej, po ponad dekadzie funkcjonowania zarzadzenia z 1924 r. wśród nauczycielek szkół powszechnych było 43,8\% mężatek. Szczegółowe dane na temat stanu cywilnego nauczycieli szkół powszechnych w roku szkolnym 1935/1936 zawiera tabela 2 .

Tabela 2. Stan cywilny nauczycieli szkół powszechnych według płci (w podziale na miasta i wieś) w roku szkolnym 1935/1936

\begin{tabular}{|c|c|c|c|c|c|c|c|c|c|c|}
\hline \multirow{3}{*}{$\begin{array}{l}\text { Nauczy- } \\
\text { ciele }\end{array}$} & \multicolumn{10}{|c|}{ Liczba nauczycieli } \\
\hline & \multicolumn{2}{|c|}{ ogólem } & \multicolumn{2}{|c|}{$\begin{array}{c}\text { stanu } \\
\text { wolnego }\end{array}$} & \multicolumn{2}{|c|}{ zamężnych } & \multicolumn{2}{|c|}{$\begin{array}{c}\text { owdowia- } \\
\text { lych }\end{array}$} & \multicolumn{2}{|c|}{$\begin{array}{c}\text { rozwie- } \\
\text { dzionych/ } \\
\text { w separacji }\end{array}$} \\
\hline & $\mathbf{M}$ & $\mathbf{K}$ & $\mathbf{M}$ & $\mathbf{K}$ & $\mathbf{M}$ & $\mathbf{K}$ & M & $\mathbf{K}$ & $\mathbf{M}$ & $\mathbf{K}$ \\
\hline ogółem & 32742 & 39979 & 10118 & 20752 & 22096 & 17269 & 375 & 1222 & 114 & 439 \\
\hline w miastach & 8146 & 12256 & 2239 & 6229 & 5736 & 5141 & 101 & 569 & 43 & 225 \\
\hline na wsi & 24596 & 27723 & 7879 & 14523 & 16360 & 12128 & 274 & 653 & 71 & 214 \\
\hline
\end{tabular}

Źródło: wyliczenia własne na podstawie: Nauczyciele w liczbach. Liczebność, cechy osobowe, zatrudnienie, uposażenie 1935/36, red. M. Falski, Warszawa 1938, s. 141.

${ }^{26}$ „Głos Nauczycielski” 1933, nr 4, s. 67.

27 AP w Poznaniu, zespół 53, Kuratorium Okręgu Szkolnego Poznańskiego w Poznaniu, Seria 1, Wydział Ogólny, sygn. 15, Nauczycielki-mężatki. Wykazy danych o zatrudnionych mężatkach w szkolnictwie. Niestety brak informacji, czy faktycznie i w jakim zakresie posłużyły one do zwolnień.

${ }_{28}$ H. Radlińska, O nowe warsztaty pracy, „Kobieta Współczesna” 1931, nr 34, s. 2. 
Niemniej w połowie lat trzydziestych wśród blisko 31 tys. nauczycieli stanu wolnego (30 870 osób) kobiety stanowiły 67,2\%. W stanie małżeńskim było niemal 40 tys. nauczycieli (39 365 osób) i przeważali wśród nich mężczyźni. Mężatek było 43,8\%. Wśród owdowiałych nauczycieli - 2,19\% ogółu nauczycieli - również przeważały kobiety (76,5\%), podobnie wśród osób rozwiedzionych (75,3\%). Należy podkreślić wszakże, że liczba kobiet samotnych w tym zawodzie wzrastała drastycznie w przypadku wsi (ponad 14,5 tys. kobiet w stosunku do ponad 7 tys. mężczyzn). Trudno jednoznacznie wskazać przyczyny tego stanu. Jak się wydaje, większe znaczenie niż nieprzychylne im prawo miały trudniejsze od miejskich realia pracy na wsi (większa ilość szkół jednoklasowych, rozproszenie szkół, etc.), skutkujące m.in. mniejszymi szansami na zawarcie związku małżeńskiego. Prawdopodobnie też na wsi kobiety częściej rezygnowały z pracy nauczycielskiej po zamążpójściu.

Z drugiej strony w przypadku Górnego Ślaska tamtejsza specyfika obyczajowa i tradycje prawne wpływały na wysokie poparcie lokalnej społeczności dla obowiąującej tam od 1926 r. ustawy „celibatowej” ${ }^{2}$. Już pod koniec 1925 r. Wydział Oświecenia Publicznego Urzędu Wojewódzkiego Śląskiego przygotował do zwolnienia listę 262 zamężnych nauczycielek, czyli 7\% ogółu zatrudnionych nauczycielek ${ }^{30}$. Wśród nich było wówczas - jak wynika z przeanalizowanych przez mnie materiałów archiwalnych - 146 nauczycielek stałych oraz 116 pomocniczych i tymczasowych $^{31}$. Ustawa $\mathrm{w}$ pierwszej kolejności objęła swoim działaniem nauczycielki tymczasowe, nie dotyczyła natomiast tych, które będąc już mężatkami, uzyskały odpowiednio wcześniej stabilizację zawodowa (miały ją dłużej niż od roku). Później co roku zwalniano ze śląskich szkół kilkadziesiąt nauczycielek, które zdecydowały się wyjść za mąż. Negatywnie zweryfikowane otrzymywały odprawy, których wysokość uzależniona była od lat dotychczasowej służby. Jednocześnie jednak traciły uzbierane składki emerytalne, samo prawo do emerytury, zniżki kolejowej i innych uprawnień związanych z wykonywanym wcześniej zawodem. Co istotne, ślaskie ustawodawstwo „celibatowe” uchwalono kilka lat po odzyskaniu niepodległości i licznych apelach o obejmowanie

29 A. Glimos-Nadgórska, Tradycjonalizm ślaski a równouprawnienie kobiet. Praca zawodowa i życie codzienne nauczycielek województwa ślqskiego (1922-1939), w: Równe prawa i nierówne szanse..., s. $158 \mathrm{nn}$.

${ }^{30}$ Tamże, s. 155-157. Ustawę przyjęto 29 III 1926 r. Równocześnie od nauczycieli mężczyzn nie wymagano statusu kawalera.

${ }^{31}$ AP w Katowicach, zespół 27/XIII, Urząd Wojewódzki Ślaski, Wydział Oświecenia Publicznego, sygn. OP-676, Statystyka nauczycielek zamężnych województwa śląskiego wg stanowiska (stan z 1 XII 1925 r.), k. 23. 
posad $\mathrm{w}$ województwie śląskim dla krzewienia tam polskości. Budziło to rozgoryczenie, zwłaszcza że przybywające na Górny Ślask nauczycielki bywały - jak już wspomniano - niemiło zaskoczone obowiązujacym prawem. Ustawodawstwo „celibatowe” zniesiono dopiero w $1938 \mathrm{r}^{32}$ Wymowne jest, że pod koniec okresu międzywojennego w województwie śląskim wśród kobiet zatrudnionych w obszarze „szkolnictwo, oświata, kultura" było 3530 panien i zaledwie 399 mężatek oraz 262 wdowy i rozwódki - był to bez wątpienia skutek opresyjnego prawa ${ }^{33}$.

Reasumując, skalę zwolnień z powodu stanu cywilnego nauczycielek szkół powszechnych na obszarze całej Polski trudno oszacować. Wspomniane kuratoryjne szacunki liczby mężatek, jakie udało się odnaleźć dzięki kwerendzie archiwalnej, dotycza jedynie Wilna (1924), Górnego Ślaska (1925) i województwa poznańskiego (1933). Jednak poza dość skrajnym przypadkiem ślaskiego prawa „celibatowego” na pozostałym obszarze Polski nie widać podobnych tendencji. Nauczycielstwo szkół powszechnych, które liczyć się musiało z koniecznością obejmowania posad na terenie całego kraju, podejmowało często udane starania o możliwość wspólnego objęcia placówki szkolnej z małżonkiem/żona czy zakończenia rozłaki z narzeczonym/narzeczona, etc. Kuratoria starały się przychylać do próśb, jeśli tylko dysponowały wolnymi posadami. W aktach Kuratorium Okręgu Szkolnego Poznańskiego zachował się dokument stanowiący zalecenie dla inspektora szkolnego dr. Jakóbca, aby w decyzjach dotyczących nauczycieli kierował się zasadą by mężatki przenosić do mężów ${ }^{34}$.

Dodać warto, że kobieca opinia publiczna i zawodowe środowiska nauczycielskie w swojej krytyce ustawodawstwa „celibatowego” nieco inaczej rozkładały akcenty. Środowiska kobiece II Rzeczypospolitej m.in. na łamach „Bluszczu” 35 czy „Kobiety Współczesnej” ostro krytykujące zarówno rozporządzenie z 1924 r., jak i śląską ustawę „celibatowa”, skupiały się - co zrozumiałe - na aspekcie nierównego traktowania pracownic ze względu na płeć. Jednak w takim samym stopniu interesowały je konsekwencje dyskryminacji w odniesieniu do nauczycielek jak np.

${ }^{32}$ Dz. U. RP 1938, nr 27, poz. 243.

${ }_{33}$ Por. G. Kempa, Edukacja dziewczat i kobiet ślaskich (od poczatku XIX wieku do wybuchu II wojny światowej), Katowice 1996, s. 166.

${ }^{34}$ AP w Poznaniu, zespół Kuratorium Okręgu Szkolnego Poznańskiego w Poznaniu, Seria 2, Wydział I Szkół Powszechnych, sygn. 63, Sprawozdania z wizytacji [wizytator Stanisław Godecki i inni] inspektoratów szkolnych, k. 132.

${ }_{35}$ Obszerna publicystykę „Bluszczu” na ten temat, w tym kwestię reakcji pisma na sytuację nauczycielek, omawia J. Chwastyk-Kowalczyk, „Bluszcz” w latach 1918-1939: tematyka społeczna oraz problemy kultury i literatury, Kielce 2003, s. 75-83. 
urzędniczek kolejowych czy biurowych, aplikantek sędziowskich, lekarek, etc. oraz dotykające ogół pracujacych kobiet nierówności płacowe ${ }^{36}$. Zwalnianie na Górnym Ślasku tych pierwszych traktowały jako egzemplifikację szerszego zjawiska. Środowisko nauczycielskie temat śląskiego prawa „celibatowego” zajmował z kolei przede wszystkim w kontekście łamania praw pracowniczych i dyskryminacji nauczycielstwa obojga płci. Już styczniu 1926 r. „Goniec Śląski” opublikował apel Związku Polskiego Nauczycielstwa Szkół Powszechnych, w którym organizacja ta oprotestowała rozważany ówcześnie projekt ustawy o zwalnianiu mężatek. Pisano w nim, że łamie on konstytucję, grozi obniżeniem wśród ogółu nauczycielek zainteresowania sprawami szkolnymi, gdyż trudno wymagać go od osoby, która zamierza pracować w szkolnictwie tylko do zamążpójścia, wreszcie „zrujnuje egzystencję rodzin nauczycielskich” i „godzi w najżywotniejsze interesy nauczycielstwa na Ślasku”. Uderzy też - zaznaczano szczególnie mocno - w Skarb tej autonomicznej dzielnicy, bowiem „w razie wprowadzenia celibatu seminaria żeńskie okazałyby się najkosztowniejszymi zakładami w stosunku do korzyści z nich płynących". Przypomniano we wspomnianej enuncjacji prasowej, że „Wydział Oświecenia Publicznego zezwolił niejednej nauczycielce tymczasowej na zamążpójście, co gwarantowało jej pozostanie w zawodzie", teraz natomiast grozi im projekt zwolnienia bez jakiegokolwiek odszkodowania, gdyż WOP wbrew swej pierwotnej decyzji odmawia stabilizacji nauczycielkom kwalifikowanym, „posiadającym po kilka lat służby”37.

Odrębna, wartą komentarza kwestią pozostaja dane dotyczące pracy zawodowej kobiet w województwie poleskim, gdzie ogólne proporcje zatrudnienia pod względem płci wśród nauczycielstwa publicznych szkół powszechnych były względnie wyrównane, jednak w drugiej połowie lat trzydziestych uległy wyraźnej zmianie na korzyść mężczyzn. Proces ten ilustruje tabela 3 .

Tabela 3. Statystyka nauczycielstwa publicznych szkół powszechnych w województwie poleskim w latach 1922-1939 według płci

\begin{tabular}{|l|r|r|r|r|r|l|}
\hline \multicolumn{1}{|c|}{ Pleć } & $\mathbf{1 9 2 2}$ & $\mathbf{1 9 2 4}$ & $\mathbf{1 9 2 6}$ & $\mathbf{1 9 2 8}$ & $\mathbf{1 9 3 6}$ & $\mathbf{1 9 3 9}$ \\
\hline Kobiety & 512 & 574 & 681 & 1059 & 1150 & 1245 \\
\hline Mężczyźni & 467 & 511 & 675 & 783 & 1153 & 1503 \\
\hline
\end{tabular}

Źródło: oprac. własne na podstawie: A. Smolarczyk, Szkolnictwo powszechne i oświata pozaszkolna w województwie poleskim w latach 1919-1939, Warszawa 2014, s. 232, 234, 248.

${ }^{36}$ H. Siemieńska, dz. cyt., s. 2-3.

${ }^{37}$ AP w Katowicach, zespół 27/XIII, Urząd Wojewódzki Śląski, Wydział Oświecenia Publicznego, sygn. OP-470, Materiały prasowe dotyczące szkolnictwa na Górnym Śląsku, k. 269. 
Nauczycielki poszukujące pracy u schyłku lat dwudziestych wobec trudności kadrowych zachęcano wręcz do obejmowania posad w tamtejszych szkołach. Rozwój oświaty na Polesiu, najbardziej zacofanym regionie II Rzeczypospolitej, pod koniec okresu międzywojennego oceniano i nagłaśniano jako „cywilizacyjny sukces”, i chociaż kryły się za tym oczywiste przesłanki polityczne i propagandowe to pod względem tempa alfabetyzacji Polesie zdystansowało inne regiony kraju ${ }^{38}$. Stopniowy spadek procentowego udziału kobiet wśród nauczycielstwa po 1928 r. mógł być wynikiem tendencji administracji oświatowej do zatrudniania kombatantów, w ocenie władz szkolnych lepiej radzących sobie w skomplikowanych warunkach panujących w powiatach nadgranicznych. Nieprzypadkowo właśnie na lata trzydzieste przypada znaczne zwiększenie nakładanych na tamtejszych nauczycieli obowiązków związanych z praca pozaszkolna - do organizacji chórów, teatrzyków i imprez przybyło prowadzenie wychowania obywatelskiego i przysposobienia wojskowego ${ }^{39}$. Jak zauważa Olga Linkiewicz, szczególnie aktywność nauczycieli mężczyzn na tym polu była poddawana wnikliwej ocenie władz administracyjnych. Czy rzeczywiście szeroko rozumiany interes państwa w tamtych warunkach lepiej realizować mieli mężczyźni, trudno stwierdzić. $\mathrm{Na}$ marginesie warto dodać, że podobną filozofię wyznawało środowisko Polskiej Macierzy Szkolnej. Uchwała z zebrania Zarządu Głównego PMS z 8 III 1935 r. głosiła: „Praca nauczyciela szkoły PMS na ziemiach wschodnich, to praca dosłownie misjonarska. [...] Na kresy muszą iść najsilniejsi, a nie - broń Boże - ci, którzy słabymi okazali się w Polsce środkowej lub zachodniej. W pierwszej linii pragniemy widzieć na tych posterunkach absolwentów seminariów nauczycielskich, którzy odbyli służbę wojskową jako podchorążowie" ${ }^{40}$. Czy normatywny charakter tej uchwały znajdował potwierdzenie w faktach, nie wiemy. Co ciekawe, kobiece zapiski pamiętnikarskie sytuację rysuja zgoła odmiennie. Jak zanotowała jedna z nauczycielek zatrudniona na Polesiu u schyłku lat trzydziestych: „do zawodu nauczycielskiego garnęły się głównie kobiety. Bardzo mało było mężczyzn, a kawalerów można było policzyć na palcach" ${ }^{41}$. Reasumując, choć stan zatrudnienia nauczycielek na tamtym

${ }_{38}$ P. Cichoracki, Województwo poleskie 1921-1939. Z dziejów politycznych, Łomianki 2014, s. 49.

${ }^{39}$ O. Linkiewicz, Lokalność i nacjonalizm. Społeczności wiejskie w Galicji Wschodniej $w$ dwudziestoleciu międzywojennym, Kraków 2018, s. 148.

${ }^{40}$ M. Iwanicki, Społeczna działalność pozaszkolna nauczycieli szkót powszechnych $w$ Polsce w latach 1918-1939, Olsztyn 1984, s. 123-124.

${ }^{41}$ K. Rafalska, Wspomnienia polskiej nauczycielki z lat 1939-1948, Brzozów-Rzeszów-Sanok 1995, s. 39. 
obszarze ulegał zmianom, które zależały zapewne od wielu czynników (ogólny spadek nakładów na oświatę i malejąca liczba posad nauczycielskich w dobie Wielkiego Kryzysu, mimo zapotrzebowania warunkowanego sytuacją demograficzna państwa), to ich płeć w warunkach nadgranicznych $\mathrm{w}$ drugiej połowie lat trzydziestych zdawała się nabierać nowego znaczenia.

$\mathrm{Na}$ pytanie, czy polityka państwa polskiego w okresie międzywojennym sprzyjała wchodzeniu kobiet w struktury publicznej oświaty powszechnej i utrwalaniu ich pozycji zawodowej trudno odpowiedzieć jednoznacznie. Przywołane warianty polityki kadrowej II Rzeczypospolitej (vide Górny Ślask, Wilno, Polesie) pokazuja, że specyficzne praktyki władzy dotykały zarówno mężatki, jak i kobiety samotne zatrudnione $\mathrm{w}$ publicznym szkolnictwie powszechnym. Z jednej strony błyskawicznie rosła liczba nauczycielek, a system finansowania oświaty w teorii nie różnicował kobiet i mężczyzn, z drugiej jednak w zależności od sytuacji znaczenia nabierały szczególnie ich stan cywilny lub ogólnie płeć. Czynniki kształtujące politykę państwa w tym zakresie pozostawały w ścisłym związku z determinantami społecznymi i ekonomicznymi, charakterystycznymi dla realiów II Rzeczypospolitej, nie sposób jednak pominąć faktu, że prawodawstwo wyróżniające mężatki z ogółu nauczycieli miało charakter dyskryminujący, i tak też było odbierane w okresie międzywojennym przez opiniotwórczą część społeczeństwa, zwłaszcza ruch kobiecy i środowisko nauczycielskich działaczy związkowych.

\section{Bibliografia}

Chwastyk-Kowalczyk J., „Bluszcz” w latach 1918-1939: tematyka społeczna oraz problemy kultury i literatury, Kielce 2003.

Cichoracki P., Województwo poleskie 1921-1939. Z dziejów politycznych, Łomianki 2014.

Cierzniewska R., Kształtowanie umiejętności zawodowych w seminariach nauczycielskich Drugiej Rzeczypospolitej, Torun 2008.

Glimos-Nadgórska A., Nauczyciele i nauczycielki: zróżnicowanie szans w zawodzie $w$ województwie ślaskim $w$ okresie międzywojennym, w: Kobieta i praca. Wiek XIX i XX. Zbiór studiów, t. 6, red. A. Żarnowska, A. Szwarc, Warszawa 2000, s. 169-178.

Glimos-Nadgórska A., Polskie szkolnictwo powszechne województwa ślaskiego 1922-1939, Katowice 2000.

Iwanicki M., Społeczna działalność pozaszkolna nauczycieli szkót powszechnych $w$ Polsce w latach 1918-1939, Olsztyn 1984.

Januszewska-Jurkiewicz J., Stosunki narodowościowe na Wileńszczyźnie $w$ latach 1920-1939, Katowice 2010. 
Juśko E., Wptyw szkolnictwa ludowego autonomicznej Galicji na kształt polskiej szkoty powszechnej w latach 1918-1922, Lublin 2006.

Kempa G., Edukacja dziewczat i kobiet ślaskich (od poczatku XIX wieku do wybuchu II wojny światowej), Katowice 1996.

Linkiewicz O., Lokalność i nacjonalizm. Społeczności wiejskie w Galicji Wschodniej w dwudziestoleciu międzywojennym, Kraków 2018.

Nauczyciele w liczbach. Liczebność, cechy osobowe, zatrudnienie, uposażenie 1935/36, red. M. Falski, Warszawa 1938.

Rafalska K., Wspomnienia polskiej nauczycielki z lat 1939-1948, Brzozów-Rzeszów-Sanok 1995.

Sanojca K., Szkoła jako instytucja pracy. Pozycja prawna i problemy zawodowe nauczycieli szkót państwowych w okresie Drugiej Rzeczypospolitej, w: Praca i społeczeństwo Drugiej Rzeczypospolitej, red. W. Mędrzecki, C. Leszczyńska, Warszawa 2014 (Metamorfozy Społeczne, 9), s. 277-291.

Smołalski A., Struktura zawodowa nauczycielstwa w Polsce do 1939 roku, Opole 1996.

Szczechura T., Zwiazek Nauczycielstwa Polskiego: zarys dziejów 1919-1939, Warszawa 1957.

Walasek S., Nauczyciele szkót średnich w Polsce w roku 1922/23 jako grupa społeczna, w: Oświata, szkolnictwo i wychowanie w latach II Rzeczypospolitej. Materiaty Ogólnopolskiej Sesji Naukowej, Lublin 7-8 listopada 1988 roku, red. K. Poznański, Lublin 1991, s. 133-138.

Żarnowski J., Kobiety w strukturze spoteczno-zawodowej Polski międzywojennej, w: Równe prawa i nierówne szanse. Kobiety w Polsce międzywojennej. Zbiór studiów, red. A. Żarnowska, A. Szwarc, Warszawa 2000, s. 95-108.

Monika Piotrowska-Marchewa

Female folk teachers. Working conditions of women in public mainstream education in interwar Poland

(Summary)

With the possibility to become teachers in the education system of the Second Polish Republic, women gained unrestricted access to working on all levels of schooling and helped trigger dynamic development of education, initiated in 1919 with the introduction of universal schooling obligation. Female teachers (almost half of the employees of this sector of education) largely hailed from the intelligentsia and petty bourgeoisie - in the early years of the Second Polish Republic, only $22.4 \%$ came from a peasant or working-class background (among men: 52\%). Even though there was no gender pay gap in the erstwhile system of mainstream education, less women were qualified to higher salary groups and they rarely assumed managing positions. When it was necessary to introduce redundancy programs due to economic struggles of the state, it became clear that the authorities were seeking to "reclaim" jobs from women 
and grant them to men in accordance with the law (e.g. the ordinance of 1924 or the so-called "Silesian celibacy act" of 1926), which resulted in dismissing married female clerks and teachers. Due to social tensions in the country, the proposal of downsizing the number of positions held by women was supported by many teachers, both male and female. After over a decade of the 1924 ordinance remaining in force, $43.8 \%$ of all female teachers in public schools were married. The factors shaping the state policy in this domain were closely connected to the dominant social and economic trends of the period; however, regulations singling out married women had an undoubtedly discriminatory character and were seen as such by the interwar women's movement and the milieu of teachers' unions. In addition, the disparate approaches to staff policy in the Second Polish Republic discussed in the article (Upper Silesia, Vilnius, Polesie) show that the particular policies of the authorities were disadvantageous not only to married female teachers but also to single women.

Monika Piotrowska-Marchewa - adiunkt w Instytucie Historycznym Uniwersytetu Wrocławskiego, studia (1998) i doktorat (2000) tamże. Zainteresowania badawcze: historia społeczna Polski 1795-1939: dzieje ubóstwa i filantropii (idee, instytucje); historia pracy i aktywności publicznej kobiet (służba domowa, oświata).

Monika Piotrowska-Marchewa - assistant professor at the Institute of History, University of Wrocław, completed graduate (1998) and doctoral (2000) studies at the same university. Research interests: social history of Poland 1795-1939; history of poverty and philanthropy (ideas, institutions); history of work and public activity of women (housekeeping, education).

E-mail: monika.piotrowska-marchewa@uwr.edu.pl. 